\title{
Pollution maps of grass contamination by platinum group elements and polycyclic aromatic hydrocarbons from road traffic
}

\author{
Abdourahamane TANKARI DAN-BADJO, Guido RYCHEN, Cecile DUCOUlOMBIER* \\ UR AFPA, Nancy-Université, INRA, 2 avenue de la Forêt de la Haye, BP 172, 54505 Vandœuvre-Lès-Nancy, France
}

(Accepted 9 June 2008)

\begin{abstract}
The increase in deposition of air pollutants such as the platinum group elements (PGEs) Pt, Pd and Rh, and polycyclic aromatic hydrocarbons (PAHs) from vehicles on plants has raised concerns about the risk for the quality of food and, in turn, for human health. Here, we report the first pollution maps of PGEs and PAHs at the agricultural scale. PGEs have recently emerged in ecosystems due to their massive use as catalysts in the automobile industry. PAHs are combustion by-products known for their carcinogenic properties. PAHs and PGEs emitted by vehicles can enter the food chain through deposition on plants growing near roads. Despite many investigations of PAHs and PGEs, knowledge on their spatial distribution near roads is very scarce. Here, we assessed their localization on the scale of an agricultural field close to a road with 7200 vehicles per day. While classical studies usually involve direct measurements of plants growing in the field, we used an alternative experimental approach to allow an unambiguous assessment of the pollution impact. Ryegrass (Lolium perenne) was first cultivated in pots in a closed greenhouse to isolate the plants from the outdoor atmosphere. Then, ryegrass pots were transferred to the agricultural field. The spatial distribution of PGEs and PAHs was assessed by placing ryegrass pots $0 \mathrm{~m}, 10 \mathrm{~m}, 25 \mathrm{~m}$ and $50 \mathrm{~m}$ from the road. This method thus allowed the measurement of PGE and PAH deposit from vehicle emissions during a known timeframe. After a one-month exposure, the PGE and PAH concentrations in ryegrass samples were analyzed by inductively coupled plasma mass spectrometry (ICP-MS) and high-pressure liquid chromatography (HPLC), respectively. Our results demonstrate a significant effect of pollution by the outdoor atmosphere for Pd and PAHs. Indeed, the concentrations increased by a factor of 1.5 for Pd and by a factor of 7 for PAHs after one month's exposure in the isolated pasture. The results also demonstrate clearly the impact of road traffic. Indeed, the highest PGE and PAH concentrations were detected in ryegrass exposed at the road site. Pd and PAH concentrations decreased significantly up to $39 \%$ and $60 \%$, respectively, from 0 to $50 \mathrm{~m}$ away from the road. The pollution maps show that the maximum depositions occur precisely along the road plan. The highest pollution levels of grasses of $23 \mathrm{ng} \mathrm{Pd} / \mathrm{g}$ grass and $260 \mathrm{ng}$ PAHs/g grass dry weight were recorded between 0 and $10 \mathrm{~m}$ on both sides of the road. Pollution maps should thus help to assess more precisely the impact of road traffic on food quality.
\end{abstract}

Pt / Pd / Rh / PAH / ryegrass / spatialization / road emission

\section{INTRODUCTION}

Road traffic is one of the most important sources of pollution in urban centres. The fast growth of private vehicle traffic and average mileage per vehicle mask the reduction of the emission rate of carbon monoxide, hydrocarbons and nitrogen oxides obtained thanks to the introduction of catalytic converters and to the use of less polluting fuels (Colvile et al., 2001). However, we are confronted with the appearance and the emergence of other pollutants: the platinum group elements (PGEs) are an example. These metal pollutants are produced by the abrasion and the deterioration of catalytic converters, and are mainly platinum $(\mathrm{Pt})$, palladium $(\mathrm{Pd})$ and rhodium $(\mathrm{Rh})$

\footnotetext{
* Corresponding author:

Cecile.ducoulombier-crepineau@ensaia.inpl-nancy.fr
}

(Ravindra et al., 2004). PGEs can have noxious effects (mutagenic and carcinogenic) on public health by contact, inhalation or consumption of contaminated products (Gebel et al., 1997; Bencs and Van Grieken, 2004). Persistent organic pollutants, in particular polycyclic aromatic hydrocarbons (PAHs), are also an essential component of road emissions. PAHs are produced during incomplete organic matter combustion at high temperature and have potentially mutagenic effects and phytotoxic effects (Shabad, 1980; Moll, 1995, Henner et al., 1999). PGE and PAH emissions due to motorway traffic represent a potential source of fodder contamination. The increase in these emissions raises the question of their accumulation in the environmental and agricultural matrices. These compounds may enter the food chain by the ingestion of contaminated fodder by dairy ruminants. Several studies revealed higher PGE concentrations (Ely et al., 2001; Djingova et al., 2003) and PAH 

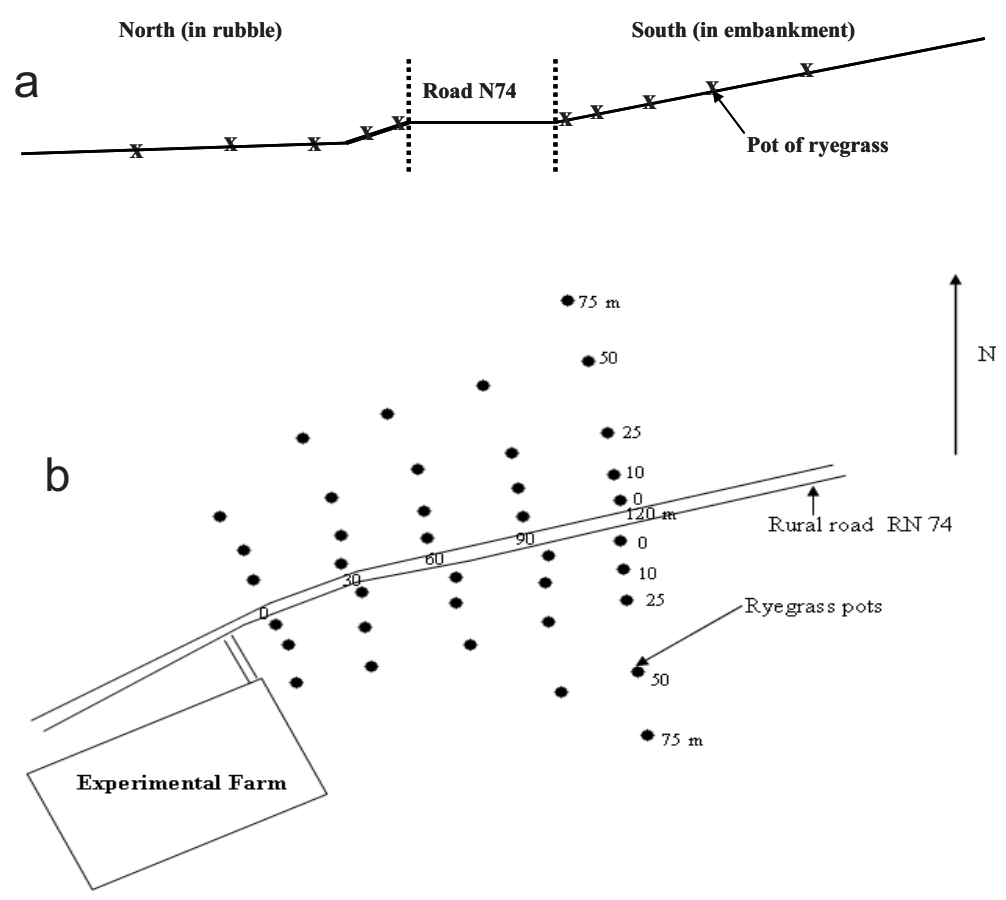

Figure 1. (a) Profile of the fodder field on both sides of the rural road (RN 74); (b) Localization of the ryegrass pots in fodder field edging the rural road. The positions were measured by GPS.

concentrations (Viskari et al., 1997; Bryselbout et al., 2000; Crépineau et al., 2003) on plants located near road sites compared with plants located in unexposed sites. However, these studies were carried out under maximum contamination conditions (distance $<10 \mathrm{~m}$ from the verge of the road). This can induce a lack of knowledge of the fodder contamination level, considering that the pastures are not very close to the roads. To complete these data, we carried out a study of spatialization of PGE and PAH contamination in a fodder field located in the vicinity of a rural road. The objective was to determine the PGE and PAH concentrations in grass located near a rural road and their distributions over a whole fodder plot scale.

\section{MATERIALS AND METHODS}

\subsection{Cultivation of ryegrass plants}

To limit the variability of in situ sampling, we used and adapted the biomonotoring method (German VDI 3957) based on the monocotyledon Lolium perenne (Garrec and Van Haluwyn, 2002), which is currently used to assess organic (Crépineau-Ducoulombier et al., 2004; Tankari Dan-Badjo et al., 2007) and metallic (Klumpp et al., 2002) contaminations in fodder. Furthermore, ryegrass is a fodder widely used in ruminant rations. In a climate chamber maintained under standardized conditions of temperature $\left(15^{\circ} \mathrm{C}\right)$, luminosity $(14 \mathrm{~h}$ of light and $10 \mathrm{~h}$ of dark) and humidity (60 to $80 \%$ ), the ryegrass was cultivated in seventy-four pots of $22.5 \mathrm{~cm}$ diameter. Each pot was filled with $5 \mathrm{~kg}$ of soil (Castorama, NF U 44-571, $23 \%$ organic matter), seeded with $1.35 \mathrm{~g}$ of seeds $\left(34 \mathrm{~g} \mathrm{~m}^{-2}\right)$ and was watered with $250 \mathrm{~mL}$ of tap water three times a week directly on the soil to avoid any washing off of the grass. One month after seeding, the ryegrass was cut every 5 days with washed scissors, $8 \mathrm{~cm}$ from the soil to stimulate growth. When exposed, the pots were put at ground level to simulate the grass in the pastures. The ryegrass was $25 \mathrm{~cm}$ above the bottom; this was enough to avoid splashes of local soil. Moreover, to avoid any contact with local grass, all vegetation had been previously removed around the pots and was regularly cut during the experiments. Pt, Pd and Rh concentrations in the soil were determined because platinum group element transfer from the soil toward the plant has previously been suspected (Schäfer et al., 1988). The concentrations were $0.25,2.1$ and $18.3 \mathrm{ng} \mathrm{g}^{-1}$ d.w., respectively, for $\mathrm{Pt}, \mathrm{Rh}$ and $\mathrm{Pd}$, which are low concentrations in soil. For PAHs, soil concentrations were not established because PAH transfer from soil toward the plant is known to be negligible (Kipopoulou et al., 1999).

\subsection{Sampling sites}

Three sites were chosen in the same area, "the Plateau Lorrain" (East of France). A major rural road (RN 74) was selected, with daily average traffic of 7200 vehicles per day, edging a fodder field at the experimental farm of the laboratory (La Bouzule). The fodder field extends over a surface of 1.8 ha separated by the RN 74 (RN 74 North and RN 74 South). The RN 74 North site is in rubble in relation to the road and the RN 74 South site side is initially flat, and then slopes while moving away from the road (Fig. 1a). The second site is an isolated pasture located $700 \mathrm{~m}$ away from any road and the third site 
is the greenhouse where the ryegrass was seeded (filtered and closed place). No industrial sites are located less than $20 \mathrm{~km}$ from the chosen sites. The rural road site and the isolated pasture are distanced by less than one kilometer to limit the variability in the climatic measurements and in the environmental parameters.

\subsection{Exposure of ryegrass pots on sites}

After 4 weeks of cultivation under controlled conditions in greenhouse, the pots of ryegrass were exposed on the sites. Two experiments were carried out. Firstly, to determine the road traffic effect, twelve pots were placed $5 \mathrm{~m}$ from the road (RN 74), directly on the soil to simulate conditions of pasture, and twelve pots were placed at the isolated pasture and twelve pots at the greenhouse.

Secondly, to analyze the spatial deposition of PGEs and PAHs, thirty-eight pots of ryegrass were exposed in a fodder field on 5 transects $30 \mathrm{~m}$ away from each other. On each transect, the pots were placed $0 \mathrm{~m}$ (edging the fence of the field), $10 \mathrm{~m}, 25 \mathrm{~m}$ and $50 \mathrm{~m}$ from the road. Thus, we obtained a grid to carry out the treatment. Using the GPSmap 60C (Garmin mark), we determined UTM (Universal Transverse Mercator) co-ordinates for each position of the pots (Fig. 1b). The ryegrass pots were exposed on all sites for 4 weeks according to our previous results on the deposition of PGE and PAH on ryegrass (Tankari Dan-Badjo et al., 2007).

\section{4. $P t, P d, R h$ and $P A H$ analysis in ryegrass}

Grass samples were dried for 5 days at $30{ }^{\circ} \mathrm{C}$, in a climate chamber, and ground (Retsch grinding) using a $1.5 \mathrm{~mm}$ sieve.

\section{Pt, Pd and Rh extraction and analysis}

The extraction and analysis of platinum group elements was performed by the "Laboratoire des Pyrenées" (Lagor, France) using the norm NF EN ISO 17294-2. The dried grass samples were mineralized using the ETHOS 1600 microwave of the Thermoelectron system. $1 \mathrm{~g}$ was placed in the digestion container. $2.5 \mathrm{~mL}$ of nitric acid $69 \%, 1 \mathrm{~mL}$ of oxygenated water $30 \%$ and $5 \mathrm{~mL}$ of deionized water were added. After agitation, the mixture was left to rest for about $12 \mathrm{~h}$. After launching of the digestion program, a progressive rise in temperature up to $160^{\circ} \mathrm{C}$ was applied to obtain a landing of mineralization. This landing was maintained for $15 \mathrm{~min}$. At the end of the digestion, the mineralized mater was taken in a vial.

Analysis of platinum group elements was done by inductively coupled plasma mass spectrometry (ICP/MS) with a VARIAN 810 UltraMass using internal standards: Iridium 194 for Pt (194-195), and Inadium 115 for Pd (106-108) and for $\mathrm{Rh}$ (104-105). The evaluation of the method was carried out following the norm XPT 90-210. For the precision of the analysis, five standard curves were used, validated by a Fisher test. Quantification limits are $0.25 \mathrm{ng} \mathrm{g}^{-1}$ d.w. for Pt and $\mathrm{Rh}$, and $0.5 \mathrm{ng} \mathrm{g}^{-1}$ d.w. for Pd.

\section{PAH extraction and analysis}

PAH extraction and analysis was performed at UR AFPAINPL (Nancy, France). PAH extraction was carried out on dried grass using the procedure described by Dugay et al. (2002). Two grams of grass were mixed with $50 \mathrm{~mL}$ toluene and placed in an ultrasound bath (SM35E-DTH, Bransonic) for $2 \mathrm{~h}$. After filtration (Cat No. 1820150, Whatman), the solution was evaporated to dryness at $40{ }^{\circ} \mathrm{C}$, and the residue saponified for $30 \mathrm{~min}$ at $60{ }^{\circ} \mathrm{C}$ with $50 \mathrm{~mL}$ of an $80 \%$ (v/v) methanol-water solution containing $1 \mathrm{M} \mathrm{KOH}$. The saponified solution was cleaned up by solid-phase extraction using OASIS HLB cartridges. After the solution was deposited, the cartridges were washed with $10 \mathrm{~mL}$ of water and the PAHs were eluted with $8 \mathrm{~mL}$ of methylene chloride. The extract containing PAHs was dried with anhydrous $\mathrm{Na}_{2} \mathrm{SO}_{4}$ and was evaporated to dryness under nitrogen using a dry bath (DB 3 Techne), and the residue was dissolved in $1 \mathrm{~mL}$ acetonitrile. The solution was stored overnight at $-20{ }^{\circ} \mathrm{C}$, before HPLC analysis.

The HPLC system included a controller (Waters 600), an autosampler (Water 717 Plus) equipped with a $20 \mu \mathrm{L}$ injection loop, a column oven (600 treater), a fluorescence detector (Waters 2475) and data processing software (Millennium 32). HPLC analysis was carried out using a Vydac 201 TP 54 column $(250 \times 4.6 \mathrm{~mm} \mathrm{ID}$, particle size $5 \mu \mathrm{m})$ with a gradient elution program using $\mathrm{H}_{2} \mathrm{O}$ and $\mathrm{CH}_{3} \mathrm{CN}$. Detection was performed by fluorimetry. All solvents were analytical- or HPLCgrade reagents. $\mathrm{KOH}$ and anhydrous $\mathrm{Na}_{2} \mathrm{SO}_{4}$ were p.a grade. Glassware was baked out at $500{ }^{\circ} \mathrm{C}$ or solvent-rinsed with toluene prior to use. PAH 610 polynuclear aromatic hydrocarbons mix was obtained from Interchim (M-610-QC).

The mobile phase comprised acetonitrile (A) and ultrapure water (B). Gradient elution conditions were as follows: 0-20 min, linear gradient 40\% A-80\% A; 20-30 min, $80 \%$ A isocratic; $30-40$ min, linear gradient $80 \%$ A-95\% A; $40-50 \mathrm{~min}, 95 \%$ A isocratic. The flow rate was $1 \mathrm{~mL} \mathrm{~min}^{-1}$. The excitation and emission wavelength program for PAH detection varied, respectively, from 250 to $295 \mathrm{~nm}$ and from 355 to $420 \mathrm{~nm}$. PAH calibration curves were performed by diluting a standard mixture (M-610-QC, Interchim) containing the 16 PAHs of the United States Environmental Protection Agency (US-EPA). The extraction yield varied from 35 to $111 \%$ according to the PAH. The final result was expressed in $\mathrm{ng} \mathrm{g}^{-1}$ d.w. weight and the quantification limit was $0.5 \mathrm{ng} \mathrm{g}^{-1}$ d.w.

\subsection{Analysis of the results}

\section{Statistical analysis}

Analysis of variance using the SAS statistical software General Linear Model (GLM) procedure was applied to the Pt, $\mathrm{Pd}$ and $\mathrm{Rh}$ concentrations, and the total PAH concentrations at the various sites. The average $\mathrm{Pt}, \mathrm{Pd}$ and $\mathrm{Rh}$ concentrations, and the total PAH concentrations obtained at the various distances $(0 \mathrm{~m}, 10 \mathrm{~m}, 25 \mathrm{~m}$ and $50 \mathrm{~m})$ were statistically analyzed 
Table I. PGE and PAH average total concentrations in ryegrass at the different sites after one month's exposure. Concentrations are given as mean values and expressed in ng. $\mathrm{g}^{-1}$ dry weight. $(\mathrm{a}, \mathrm{b}, \mathrm{c})$, for each column, mean results without the same letter differ significantly, $P<0.05 ;$ nd: not detected.

\begin{tabular}{lcccc}
\hline & $\mathrm{Pt}$ & $\mathrm{Rh}$ & $\mathrm{Pd}$ & $\sum \mathrm{PAH}$ \\
\hline $\begin{array}{l}\text { Greenhouse } \\
\begin{array}{l}\text { Isolated pasture } \\
\text { (Bouzule) }\end{array}\end{array}$ & $\mathrm{nd}$ & $1.7 \mathrm{a}$ & $3.5 \mathrm{c}$ & $13.0 \mathrm{c}$ \\
$\begin{array}{l}\text { Road site } \\
\text { (RN 74, 5 m from }\end{array}$ & 0.7 & $1.5 \mathrm{a}$ & $5.5 \mathrm{~b}$ & $86.0 \mathrm{~b}$ \\
the road) & & & $12.4 \mathrm{a}$ & $346.0 \mathrm{a}$ \\
\hline
\end{tabular}

with the same procedure. The threshold of significance is $5 \%$ $(P<0.05)$.

\section{Use of the geographical information system software (GIS MapInfo)}

GIS MapInfo allocates to each UTM co-ordinate the corresponding $\mathrm{Pt}, \mathrm{Rh}, \mathrm{Pd}$ and $\mathrm{PAH}$ concentrations by using the IDW method (Inverse Distance Weight). The IDW method is a classic interpolation method which permits the calculation of a set of values for a surface between two known points. It allows the referring of the PGE and PAH exposure levels on site starting from the concentrations measured in the ryegrass. We obtain the curves or classes of the same level of pollution or "isopols" by measurements of interpolation between concentrations of the same value. This treatment makes it possible to obtain a representation by continuous color.

\section{RESULTS AND DISCUSSION}

\subsection{Concentrations and profiles of PGE and PAH in ryegrass at the various sites}

The results obtained for Pt, Rh, Pd and total PAH concentrations in ryegrass samples from the various sites are shown in Table I. Pt concentration was $0.7 \mathrm{ng} \mathrm{g}^{-1}$ d.w. and detected only at the road site. Rh concentrations ranged from 1.5 to $1.9 \mathrm{ng} \mathrm{g}^{-1}$ d.w. and did not vary significantly according to the exposure sites. The Pd and total PAH concentrations were significantly higher in grass from the isolated pasture than in grass from the greenhouse, revealing the effect of the outside atmosphere. This deposition of Pd and PAH on the ryegrass comes from the atmosphere and demonstrates that Pd and PAH pollution occurs in all types of sites, even when the fodder is far from any sources. The Pd and PAH compounds could therefore be considered as ubiquitous in the environment and transported with particles and gases over long distances (Barbante et al., 2001).

Comparing the ryegrass exposed along the roadway and the ryegrass at the isolated pasture and greenhouse, the Pd and PAH concentrations were significantly higher at the road site, suggesting the effect of road traffic. The difference between the Pd and PAH concentrations in grass from the greenhouse and in grass from the road site is of a factor 2.2 and 26, respectively. Road traffic also had an influence on the Pt concentrations, which were only detected at this site. These results show that PGE and PAH contamination of grass near roadways is enhanced by vehicular traffic and demonstrate a potential risk of grass contamination for pastures along roads.

The PGE distribution in ryegrass was found to be different according to the sampling sites. In grass at the road site, all PGEs ( $\mathrm{Pt}, \mathrm{Pd}$ and $\mathrm{Rh}$ ) were detected, while at the isolated pasture and the greenhouse, Pt was not detected. Pd was the major compound, followed by $\mathrm{Rh}$ and Pt. Indeed, Pd concentration represented $68 \%, 78 \%$ and $82 \%$ of the total PGE concentration, respectively, at the greenhouse, the isolated pasture and the road site.

Analyses of PAH in ryegrass pots also show different profiles at the various sites (Tab. II). At the greenhouse, only phenanthrene and pyrene were found. On the isolated site, in addition to these two PAHs, anthracene and fluoranthene were detected. In ryegrass pots exposed at the road site, all twelve PAHs were detected. At the pasture and the greenhouse sites no highmolecular-weight compounds (benzo(a)anthracene, chrysene, benzo(b)fluoranthene, benzo(k)fluoranthene, benzo(a)pyrene and benzo(g,h,i)perylene), which present a high toxicity, were detected in the ryegrass, nor any compounds with more than four aromatic rings. Pyrene was the major common compound for all the sites but its concentration at the road site was 2 and 14 times higher, respectively, than at the isolated site and at the greenhouse. When the pots of ryegrass were not exposed (greenhouse only), pyrene and phenanthrene represented, respectively, $41.3 \%$ and $58.7 \%$ of the total PAH concentrations. At the isolated site, the percentage of phenanthrene (39.9\%) and pyrene $(36.5 \%)$ decreased with the detection of anthracene and fluoranthene. When the ryegrass pots were exposed at the road site, the concentrations of phenanthrene and pyrene decreased to reach levels of $13.8 \%$ and $21.5 \%$, respectively, with the detection of high-molecular-weight PAHs (Tab. II).

The profiles detected in ryegrass revealed that the contamination of fodder differs according to the site. This result suggests a different level of contaminants ingested by dairy cows grazing on pastures located in these different kinds of sites. The compounds detected at the road site are numerous and present potential risks of toxicity as carcinogenic compounds were detected in the ryegrass pots.

\subsection{Concentrations and profiles of PGE and PAH in ryegrass according to the distance from the road}

The average Pd, Rh and Pt concentrations, and the average total PAH concentrations (means of the values obtained at the same distance) according to the road distance $(0,10,25$ and $50 \mathrm{~m}$ ) are given in Table III. For Pt and Rh, the concentrations did not vary significantly with the road distance. The fastest decline for PGE concentrations in ryegrass was found for Pd, whose concentration varied from 17.3 to $10.9 \mathrm{ng} \mathrm{g}^{-1} \mathrm{~d}$.w. The average Pd concentration decreased significantly to $39 \%$ from 
Table II. PAH profiles in ryegrass at the various sites. Concentrations are given as mean values, expressed in ng. $\mathrm{g}^{-1}$ dry weight and in $\%$ of the total PAH concentration. nd: not detected.

\begin{tabular}{|c|c|c|c|c|c|c|}
\hline \multirow[t]{2}{*}{ Compounds } & \multicolumn{2}{|c|}{ Greenhouse } & \multicolumn{2}{|c|}{$\begin{array}{c}\text { Isolated pasture } \\
\text { (Bouzule) }\end{array}$} & \multicolumn{2}{|c|}{$\begin{array}{l}\text { Road site } \\
\text { (RN 74) }\end{array}$} \\
\hline & $\begin{array}{l}\text { ng. }{ }^{-1} \\
\text { d.w. }\end{array}$ & $\%$ & $\begin{array}{l}\text { ng. } \mathrm{g}^{-1} \\
\text { d.w. }\end{array}$ & $\%$ & $\begin{array}{l}\text { ng.g }{ }^{-1} \\
\text { d.w. }\end{array}$ & $\%$ \\
\hline Acenaphtene & nd & - & nd & - & 1,1 & 0.3 \\
\hline Phenanthrene & 7.5 & 58.7 & 34.5 & 39.9 & 47.8 & 13.8 \\
\hline Anthracene & nd & - & 2.1 & 2.5 & 1.8 & 0.5 \\
\hline Fluoranthene & nd & - & 18.2 & 21.1 & 63.1 & 18.3 \\
\hline Pyrene & 5.3 & 41.3 & 31.6 & 36.5 & 74.2 & 21.5 \\
\hline Benzo(a)anthracene & nd & - & nd & - & 14.2 & 4.1 \\
\hline Chrysene & nd & - & nd & - & 22.2 & 6.4 \\
\hline Benzo(b)fluoranthene & nd & - & nd & - & 44.2 & 12.8 \\
\hline Benzo(k)fluoranthene & nd & - & nd & - & 17.0 & 4.9 \\
\hline Benzo(a)pyrene & nd & - & nd & - & 22.6 & 6.5 \\
\hline Dibenzo(a,h)anthracene & nd & - & nd & - & 2.6 & 0.8 \\
\hline Benzo(g,h,i)perylene & nd & - & nd & - & 34.8 & 10.1 \\
\hline
\end{tabular}

Table III. Platinum group element (PGE) and polycyclic aromatic hydrocarbon (PAH) average concentrations in ryegrass according to the distance from the road. Concentrations are given as mean values and expressed in ng. $\mathrm{g}^{-1}$ dry weight. (a,b,c), for each line, mean results without the same letter differ significantly, $P<0.05$. NSV: no significant variation between concentrations at $0 \mathrm{~m}$ and $50 \mathrm{~m}$.

\begin{tabular}{|c|c|c|c|c|c|}
\hline Compounds & $0 \mathrm{~m}$ & $10 \mathrm{~m}$ & $25 \mathrm{~m}$ & $50 \mathrm{~m}$ & $\begin{array}{c}\text { Percentage of } \\
\text { decrease between } 0 \\
\text { and } 50 \mathrm{~m}\end{array}$ \\
\hline \multicolumn{6}{|c|}{ PGE } \\
\hline Rhodium & $1.8 \mathrm{a}$ & $1.5 \mathrm{a}$ & $1.5 \mathrm{a}$ & $1.6 \mathrm{a}$ & NSV \\
\hline Palladium & $17.3 \mathrm{a}$ & $14.1 \mathrm{~b}$ & $11.0 \mathrm{c}$ & $10.6 \mathrm{c}$ & $39 \%$ \\
\hline Platinum & $0.3 \mathrm{a}$ & $0.2 \mathrm{a}$ & $0.3 \mathrm{a}$ & $0.2 \mathrm{a}$ & NSV \\
\hline \multicolumn{6}{|c|}{ PAHs } \\
\hline Acenaphtene & $6.8 \mathrm{a}$ & $6.1 \mathrm{ab}$ & $4.5 \mathrm{ab}$ & $3 \mathrm{~b}$ & $56 \%$ \\
\hline Phenanthrene & $71.4 \mathrm{a}$ & $41.6 \mathrm{~b}$ & $22.3 \mathrm{~b}$ & $23.2 \mathrm{~b}$ & $67 \%$ \\
\hline Anthracene & $0.6 \mathrm{a}$ & $0.6 \mathrm{a}$ & $0.9 \mathrm{a}$ & $1.2 \mathrm{a}$ & NSV \\
\hline Fluoranthene & $20.2 \mathrm{a}$ & $10.5 \mathrm{~b}$ & $13.4 \mathrm{ab}$ & $11.7 \mathrm{ab}$ & NSV \\
\hline Pyrene & $40.5 \mathrm{a}$ & $33.7 \mathrm{ab}$ & $14.9 \mathrm{c}$ & $20.1 \mathrm{bc}$ & $51 \%$ \\
\hline Benzo(a)anthracene & $1.9 \mathrm{a}$ & $1.1 \mathrm{~b}$ & $1.4 \mathrm{ab}$ & $0.9 \mathrm{~b}$ & $52 \%$ \\
\hline Chrysene & $2.8 \mathrm{a}$ & $3.3 \mathrm{a}$ & $1.4 \mathrm{a}$ & $1.1 \mathrm{a}$ & NSV \\
\hline Benzo(b)fluorantene & $3.8 \mathrm{a}$ & $2.1 \mathrm{~b}$ & $1.6 \mathrm{~b}$ & $1.3 \mathrm{~b}$ & $66 \%$ \\
\hline Benzo(k)fluorantene & $1.5 \mathrm{a}$ & $1.5 \mathrm{a}$ & $1.2 \mathrm{a}$ & $0.6 \mathrm{a}$ & NSV \\
\hline Benzo(a)pyrene & $28 \mathrm{a}$ & $15.9 \mathrm{~b}$ & $7.5 \mathrm{~b}$ & $7.4 \mathrm{~b}$ & $73 \%$ \\
\hline Dibenzo(a,h)anthracene & $0.4 \mathrm{ab}$ & $0.5 \mathrm{a}$ & $0.4 \mathrm{ab}$ & $0.2 \mathrm{~b}$ & NSV \\
\hline Benzo(g,h,i)perylene & $2.9 \mathrm{a}$ & $1.4 \mathrm{~b}$ & $1.7 \mathrm{ab}$ & $1.3 \mathrm{~b}$ & $55 \%$ \\
\hline Total PAHs & $180.4 \mathrm{a}$ & $119 \mathrm{~b}$ & $72.6 \mathrm{c}$ & $72.1 \mathrm{c}$ & $60 \%$ \\
\hline
\end{tabular}

$0 \mathrm{~m}$ to $50 \mathrm{~m}$. This Pd decrease corresponds to a PGE decrease in concentrations detected in mosses with the increased distance from the road (Zechmeister et al., 2006). Pd compounds remained the major compounds for all distances from the road. The highest Pd concentrations in ryegrass could be explained by the properties of the Pd compounds, which are more soluble and more mobile in the environment than $\mathrm{Pt}$ and $\mathrm{Rh}$ compounds (Moldovan et al., 2001) and therefore more bioavailable for plants. Also, the Pd concentration in the environment has been increasing over the last ten years (Zereini et al., 2007).

The total PAH average concentrations varied significantly between $180 \mathrm{ng} \mathrm{g}^{-1}$ d.w. and $72 \mathrm{ng} \mathrm{g}^{-1}$ d.w. from 0 to $50 \mathrm{~m}$ from the road. Unlike Pd, which has a slow and progressive decrease $(39 \%)$, the decrease in total PAHs with the dis- tance from the road reaches $60 \%$ at $50 \mathrm{~m}$. The decrease in the concentrations between 0 and $50 \mathrm{~m}$ differs according to the PAH compound. Four types of behavior were observed. Anthracene, chrysene and benzo(k)fluorantene do not vary significantly with the increase in the road distance. Fluorantene decreases significantly only between 0 and $10 \mathrm{~m}$ from the road. For dibenzo(a,h)anthracene, the variation is irregular. For the seven remaining PAHs (acenaphtene, phenanthrene, pyrene, benzo(a)anthracene, benzo(b)fluoranthene, benzo(a)pyrene and benzo(g,h,i)perylene) the concentrations decreased significantly with the distance from the road (Tab. III). However, this decrease in PAH concentrations does not seem to be affected by the molecular weight or the number of aromatic rings of the compounds. For example, benzo(a)pyrene and benzo(b)fluorantene, which have the same 


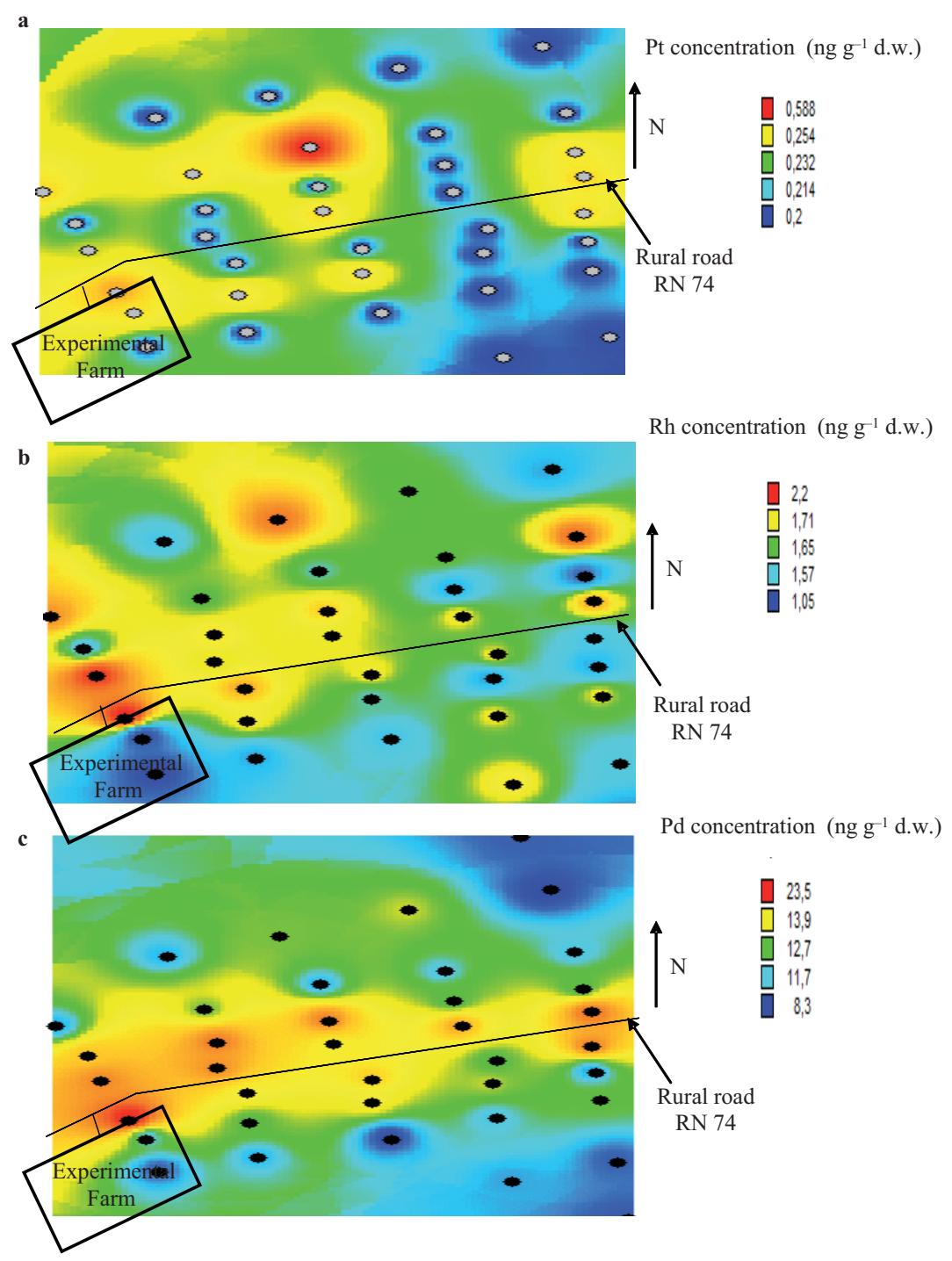

Figure 2. Spatialization of $\mathrm{Pt}(\mathrm{a}), \mathrm{Rh}(\mathrm{b})$ and $\mathrm{Pd}(\mathrm{c})$ deposition on ryegrass at a fodder field edging a road site. Relation between the concentration values and the road distance. Note the adequation of the high concentration of Pd and the proximity of the road.

molecular weight and the same number of aromatic rings, decreased by $73 \%$ and $66 \%$, respectively. The situation was the same for acenaphtene $(56 \%)$ and phenanthrene $(67 \%)$. This could be explained by the air movement around the road and the deposition and resuspension of PAHs.

Comparing the exposed ryegrass in the isolated pasture (considered as a "background" site) with the ryegrass exposed $50 \mathrm{~m}$ from the road, there were considerable similarities and differences in the average $\mathrm{Pd}$ concentrations and in the PAH profiles and concentrations. Similarity only related to the total PAH concentration between the two sites $\left(86 \mathrm{ng} \mathrm{g}^{-1} \mathrm{~d}\right.$.w. in the isolated pasture and $72 \mathrm{ng} \mathrm{g}^{-1}$ d.w. $50 \mathrm{~m}$ from the road). This result suggests that the background value for total PAH concentration in grass was reached $50 \mathrm{~m}$ from the road. For $\mathrm{Pd}$, the concentration was still two times higher $50 \mathrm{~m}$ from the road (10 $\mathrm{ng} \mathrm{g}^{-1} \mathrm{~d}$.w.) than at the isolated site $\left(5 \mathrm{ng} \mathrm{g}^{-1} \mathrm{~d} . \mathrm{w}.\right)$, suggesting that the Pd background value was not reached before a distance of $50 \mathrm{~m}$ from the road. Pd particles are probably transported a long distance, as has been shown for PGE occurrence in alpine snow (Van der Velde et al., 2000) and remote Greenland snow (Barbante et al., 2001).

The difference was most evident for the PAHs, which were more numerous and varied more $50 \mathrm{~m}$ from the road than at the isolated site. Indeed, twelve PAHs were detected $50 \mathrm{~m}$ from the road compared with four PAHs (Phenanthrene, anthracene, fluoranthene and pyrene) at the isolated site. This result confirms again that the heavy PAHs (5 to 6 aromatic rings) associated with particulate matters were not transported over long distances (Crépineau et al., 2003).

\subsection{Spatialization of PGE and total PAH deposition on ryegrass at the fodder field}

Figures 2 and 3 show the spatialization of PGE and $\mathrm{PAH}$ concentrations at the pasture. Five classes of decreasing 


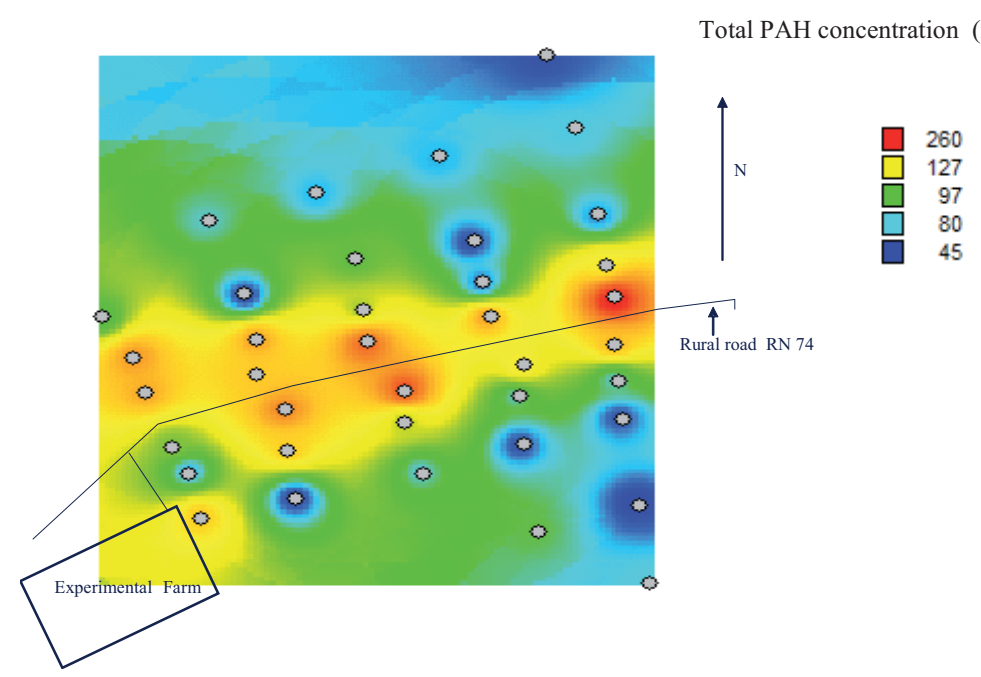

Figure 3. Spatialization of total PAH deposition on ryegrass at a fodder field edging a road site. Relation between the concentration values and the road distance. Note the adequation of the high concentration of PAH and the proximity of the road.

concentrations symbolized by five different colors (red, yellow, green, light blue and dark blue) were used to establish these maps. For Pt and Rh, the distribution of their concentrations in the fodder plot was heterogeneous: the different classes of concentrations were not directly linked to the distance from the road. The analyses of Pd and PAH maps showed the first result of this nature: on each map, the sampling area along the road plan showed the highest concentrations. For the first time, Pd and PAH deposition on ryegrass is spatialized on the whole scale of a fodder field and it confirms the decrease in concentrations obtained with the transects. The highest values were observed between 0 and $10 \mathrm{~m}$ away from the road with a maximum of $23 \mathrm{ng} \mathrm{g}^{-1}$ d.w. for Pd and $260 \mathrm{ng} \mathrm{g}^{-1}$ d.w. for the total PAHs. The decreased distribution of Pd and PAH in the fodder field with increasing road distance was observed on both sides of the road. When analyzing the Pd and PAH distribution on two sides of the road, the ryegrass pots exposed at the north side of the road revealed higher concentrations than the ryegrass pots exposed at the south side. This result suggests the effect of the topography and the prevailing wind coming from the south-west. As shown in previous studies of grasses or soils, there is an influence of wind direction and wind speed on PGE (Schäfer and Puchelt, 1998) and PAH distribution (Mastral et al., 2003). The maps show that the repartition of Pd and PAHs occur precisely along the road plan. It is of great concern to assess the risk of pollutant deposition which is limited to the risk of transfer in the food chain.

\section{CONCLUSION}

The use of the biomonitoring method allowed a real comparison of ryegrass contamination by PGE and PAH at 3 sites. The results showed that Pd concentrations and total PAH concentrations reaching, respectively, up to $23 \mathrm{ng} \mathrm{g}^{-1}$ d.w. and $345 \mathrm{ng} \mathrm{g}^{-1} \mathrm{~d}$.w. were detected on the ryegrass exposed along the road. The PGE and PAH profiles obtained revealed that the contamination of fodder was not similar according to the sites. Pt was detected only on the road site. The carcinogenic compounds (benzo(a)anthracene, chrysene, benzo(b)fluorantene, benzo(k)fluorantene, benzo(a)pyrene and benzo(g,h,i)perylene), which have a high toxicity (TEF: $0.01-1$ ), were found only in ryegrass exposed along the road site.

Pd and PAH concentrations decreased significantly with increasing distance from the road. However, the reduction of the PAH concentration (60\%) was higher than the Pd concentration decrease (39\%). The maps of spatialization of Pd and PAH deposition on ryegrass in all fodder fields confirm these results for the first time. The pollution was detectable up to $50 \mathrm{~m}$ from the road. Nevertheless, the major contamination took place next to the road $(0-10 \mathrm{~m})$. As it is known that PAHs, PAH metabolites and Pd are detected in milk there is a potential risk for ruminants grazing between 0 and $10 \mathrm{~m}$ from the road to transfer pollutants. It is necessary to widen the spatialization to other pollutants on other fodder species and to soils.

\section{REFERENCES}

Barbante C., Veysseyre A., Ferrari C., Van de Velde K., Morel C., Capodaglio G., Cescon P., Scarponi G., Boutron C. (2001) Greenland snow evidence of large scale atmospheric contamination for platinum, palladium and rhodium, Environ. Sci. Technol. $35,835-839$.

Bencs L., Van Grieken R. (2004) Platinum group elements in the environment and their health risk, Sci. Total Environ. 318, 1-47.

Bryselbout C., Henner P., Carsignol J., Lichtfouse E. (2000) Polycyclic aromatic hydrocarbons in highway plants and soils. Evidence for a local distallation effet, Analusis 28, 32-35.

Colvile R.N., Hutchinson E.J., Mindell J.S., Warren R.F. (2001) The transport sector as a source of air pollution, Atmos. Environ. 35, $1537-1565$. 
Crépineau-Ducoulombier C., Tankari D.A., Rychen G. (2004) PAH contamination of the grass perenne exposed to vehicular traffic, Agronomie 24, 503-506.

Crépineau C., Rychen G., Feidt C., Le Roux Y., Lichtfouse E., Laurent F. (2003) Contamination of pastures by polycyclic aromatic hydrocarbons (PAHs) in the vicinity of a highway, J. Agr. Food Chem. 51, $4841-4845$.

Djingova R., Kovacheva P., Wagner G., Markert B. (2003) Distribution of platinum group elements and other traffic related elements among different plants along some highways in Germany, Sci. Total Environ. 308, 235-246.

Dugay A., Herrenknecht C., Czok M., Guyon F., Pages N. (2002) New procedure for selective extraction of polycyclic aromatic hydrocarbons in plants for gas chromatographic - mass spectrometric analysis, J. Chromato. 958, 1-7.

Ely J.C., Neal C., Kulpa C., Schneegurt M., Seidler J., Jain J. (2001) Implications of platinum-group element accumulation along US roads from catalytic-converter attrition, Environ. Sci. Technol. 35, 3816-3822.

Garrec J.P., Van Haluwyn C. (2002) Biosurveillance végétale de la qualité de l'air, Tec \& Doc, Paris, 117 p.

Gebel T., Lantzsch H., Plesow K., Dunkelberg K. (1997) Genotoxicity of platinum and palladium compounds in human and bacterial cells, Mutat. Res. 389, 183-190.

Henner P., Schiavon M., Druelle V., Lichtfouse E. (1999) Phytotoxicity of ancient gaswork soils. Effect of polycyclic aromatic hydrocarbons (PAHs) on plant germination, Org. Geochem. 30, 963-969.

Kipopoulou A.M., Manoli E., Samara C. (1999) Bioconcentration of polycyclic hydrocarbons in vegetables grown in an industrial area, Environ. Poll. 106, 369-380.

Klumpp A., Ansel W., Klumpp G., Belluzzo N., Calatayud V., Chaplin N., Garrec J.P., Gutsche H.J., Hayes M., Hentze H.W., Kambezidis H., Laurent O., Penuelas J., Rasmussen S., Ribas A., Ro-Poulsen H., Rossi S., Sanz M.J., Shang H., Sifakis N., Vergne P. (2002) EuroBionet: A Pan - European Biomonitoring Network for Urban Air Quality Assessment, Environ. Sci. Pollut. R. 9, 199-203.

Mastral A.M., Lopez J.M., Callén M.S., Garcia T., Murrillo R., Navaro M. (2003) Spatial and temporal PAH concentrations in Zaragoza, Spain, Sci. Total Environ. 307, 111-124.
Moldovan M., Rauch S., Gómez M., Palacios M.A., Morrison G.M. (2001) Bioaccumulation of palladium, platinum and rhodium from urban particulates and sediments by the freshwater isopod Asellu, Water Res. 35, 4175-4183.

Moll N. (1995) Évaluations de la contamination des aliments et boissons par les hydrocarbures aromatiques et les amines hétérocycliques, in: Moll M., Moll N. (Eds.), Sécurité alimentaire du consommateur, Technique et Documentation Lavoisier, pp. 264-282.

Ravindra K., Bencs L., Van Grieken R. (2004) Platinum group elements in the environment and their health risk, Sci. Total Environ. 318, $1-47$.

Schäfer J., Hannker D., Eckhardt J.D., Stuben D. (1998) Uptake of trafficrelated heavy metals and platinum group elements (PGE) by plants, Sci Total Environ. 215, 59-67.

Schäfer J., Puchelt H. (1998) Platinum-Group-Metals (PGM) emitted from automobile catalytic converters and their distribution in roadside soils, J. Geochem. Explor. 64, 307-314.

Shabad L.M. (1980) Circulation of carcinogenic Polycyclic Aromatic Hydrocarbons in the human environment and cancer prevention, J. Natl. Cancer I. 64, 405-410.

Tankari Dan-Badjo A., Crépineau C., Soligot C., Feidt C., Rychen G. (2007) Deposition of platinum group elements and polycyclic hydrocarbons on ryegrass exposed to vehicular traffic, Agron. Sustain. Dev. 27, 261-266.

Van der Velde K., Barbante C., Cozzi G., Moret I., Bellomi T., Ferrari C., Boutron C. (2000) Changes in the occurence of silver, gold, platinum, palladium, and rhodium in Mont Blanc ice and snow since the 18th century, Atmos. Environ. 34, 3117-3127.

Viskari E.L., Rekilä R., Roy S., Lehto O., Ruuskanen J., Kärenlampi L. (1997) Airborne pollutants along a roadside: assessment using snow analyses and moss bags, Environ. Pollut. 153-160.

Zechmeister H.G., Hagendorfer H., Hohenwallner D., Hanus-Illnar A., Riss A. (2006) Analyses of platinum group elements in mosses as indicators of road traffic emissions in Austria, Atmos. Environ. 40, $7720-7732$.

Zereini F., Skerstupp B., Alt F., Helmers E., Urban H. (2007) Geochemical behaviour of platinum-group elements (PGE) in particulate emissions by automobile exhaust catalysts: experimental results and environmental investigations, Total Environ. 7, 37-146. 